\title{
CHEMICAL SOIL ATTRIBUTES EVALUATED BY MULTIVARIATE TECHNIQUES AND GEOSTATISTICS IN THE AREA WITH AGROFORESTRY AND SUGARCANE IN HUMAITÁ, AM, BRAZIL
}

\author{
ATRIBUTOS QUÍMICOS DO SOLO AVALIADOS POR TÉCNICAS MULTIVARIADAS \\ E GEOESTATÍSTICAS EM ÁREA COM AGROFLORESTA E CANA-DE-AÇÚCAR EM \\ HUMAITÁ, AM, BRASIL
}

\section{Renato Eleoterio de AQUINO ${ }^{1}$; Milton Cesar Costa CAMPOS $^{2}$; Marcelo Dayron Rodrigues SOARES ${ }^{3}$; Ivanildo Amorim de OLIVEIRA ${ }^{\mathbf{1}}$;} Uilson FRANCISCON ${ }^{4}$; Douglas Marcelo Pinheiro SILVA ${ }^{2}$; José Maurício CUNHA ${ }^{2}$

1. PhD student in Soil Science, Universidade Estadual Paulista - UNESP, Jaboticabal, SP, Brasil. aquino.rea@ gmail.com; 2. Professor, Doutor, Universidade Federal do Amazonas - UFAM, Humaitá, AM, Brasil; 3. PhD student in FEAGRI, Universidade de Campinas UNICAMP, Campinas, SP, Brasil; 4. Majoring in Environmental Engineering, Universidade Federal do Amazonas, UFAM, Humaitá, AM, Brasil.

\begin{abstract}
Studies on the spatial behavior of soil attributes in the Amazon region are still very incipient. In this sense, the objective of this work was to evaluate the chemical attributes through multivariate techniques and geoestatistics in the area with agroforestry and sugarcane in Humaitá, AM, Brazil. The study was carried out in a farm in Humaitá city, Amazonas State. The studied area was divided into $70.00 \mathrm{~m} \mathrm{x} 70.00 \mathrm{~m}$ meshes with a regular spacing of 10 $\mathrm{m}$, totaling 64 points and then, soil samples were collected at 0.0-0.2 $\mathrm{m}$ and 0.4-0.6 m depths. We performed chemical analyses of the attributes of soil. Then, it was applied descriptive statistics, multivariate and geostatistics. In conclusion, our findings suggest that for most of the chemical attributes was observed spatial dependence in both areas, with DSD varying from weak to moderate, with prevalence of the weak one. The multivariate analysis was efficient in the selection of chemical soil attributes that best represented the agroforestry environments and sugarcane. The results of this study will serve as a basis for further studies on these environments and other systems within the region; moreover serving as a basis for agricultural planning aiming a better environmental sustainability.
\end{abstract}

KEYWORDS: Spatial variability. Soil attributes. Southern Amazonas.

\section{INTRODUCTION}

Soil property variability is generated over time by intensity of soil forming processes (BURROUGH, 1993) and influenced by human activities (SILVEIRA et al., 2000). The knowledge on soil variability may allow a better understanding of relationships between the attributes and environmental factors (GOOVAERTS, 1998) and can help in determining specific management practices (PLANT, 2001); thus contributing to a better sustainable management and minimizing environmental impacts.

In this sense, the use of multivariate analysis technique you can explain as much intercorrelação between the variables and find out which ones contribute more to the characterization and, or, alteration of soil. Na análise simultânea de muitas informações, esta técnica torna-se a melhor ferramenta (CRUZ; REGAZZI 2001). Using set of multivariate techniques can assist in decisionmaking the use and proper management of soil, based on the behavior of its attributes, and indicate the attributes that suffer greater change with the anthropic action (OLIVEIRA et al., 2015).

Spatial variability study through geostatistics enables the interpretation of the results based on natural variability structure of evaluated attributes, taking into account the spatial dependence within the sampling interval (SOUZA et al., 2008). However, it is necessary to provide an accurate and reliable sampling to avoid serious interpretation errors (CRUZ et al., 2010).

Nevertheless, there are few studies on spatial behavior of soil attributes in Northern Brazil. Being non-existent chemical attributes studies still in soils under regenerated areas with agroforestry systems. By contrast, it is observed in literature several studies of this variability in soils under sugarcane cropping throughout Brazil (PELUCO et al., 2015; AQUINO et al., 2014; MARQUES JR et al., 2014).

Chemical attribute spatial variability is not only conditioned by soil genesis factors, but also temporal events, different crops and applied treatments within a seemingly homogeneous area (CAON, 2012). Several studies show correlation or 
spatial dependence of soil chemical attribute variability (PELUCO et al., 2013; DALCHIAVON et al., 2014; BOTTEGA et al., 2013).

In this context, considering the lack of studies on spatial behavior of chemical attributes in Amazonas region, the objective of this work was to evaluate the chemical attributes through multivariate techniques and geoestatistics in the area with agroforestry and sugarcane in Humaitá, AM, Brazil. The results may help further studies on studies of spatial variability characterization, mapping and cause and effect.

\section{MATERIAL AND METHODS}

The study was conducted at two farms located within Humaitá County, Amazonas State in Northern Brazil. Sugarcane area is located at $7^{\circ} 54^{\prime}$ $38^{\prime \prime} \mathrm{S}$ and $63^{\circ} 14^{\prime} 27^{\prime \prime} \mathrm{W}$ geographical coordinates with an average altitude of $70 \mathrm{~m}$; and the agroforestry area is located at $7^{\circ} 28^{\prime} 29^{\prime \prime} \mathrm{S}$ and $63^{\circ}$ $02^{\prime} 07^{\prime \prime} \mathrm{W}$ geographical coordinates at an average altitude of $63 \mathrm{~m}$ above sea level (Figure 1).

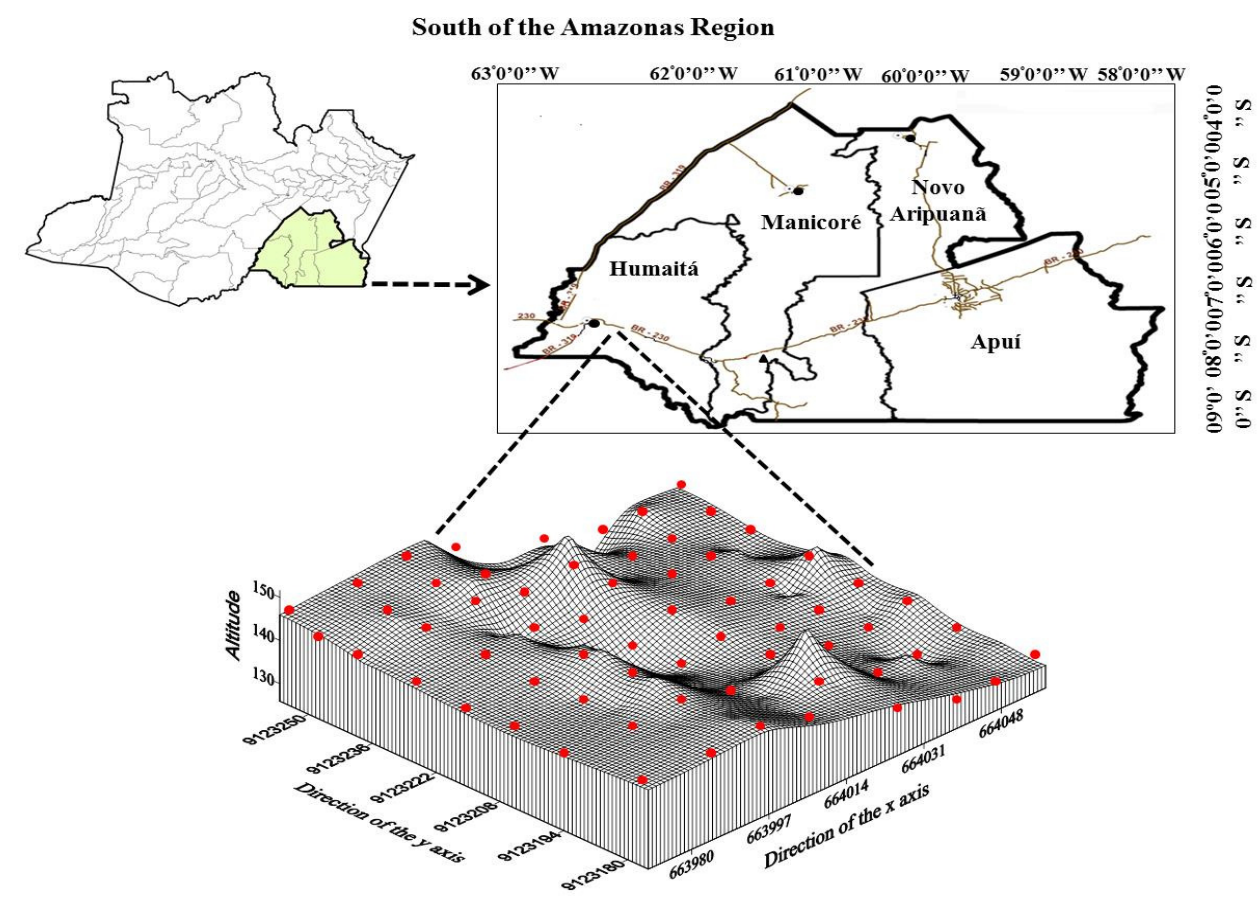

Figure 1. Model Digital Elevation and location of the area of sugar cane and area with agroforestry's in the region in Humaitá-AM.

According to Köppen Classification, local climate is a rainy tropical type $(\mathrm{Am})$ (monsoon rain type). The temperatures range between 25 and 27 ${ }^{\circ} \mathrm{C}$, average annual rainfall is $2,500 \mathrm{~mm}$ with a short dry period and rainy season from October to June, and relative humidity between 85 and $90 \%$. In both areas the soil was classified as Alitic Plinthic Cambisol (CXalf) according to Embrapa (2013) (Inceptisol).

The area of sugarcane has more than eight years, with manual harvest after firing; last year, the Office performed the cutting and burning of the plants, for renewal of the crop. The area has approximately 17 years agroforestry cultivated with fruit Amazonian species (cacao, açaí, cupuaçu, bacaba, manga etc.); However, the area was managed with implements manuals, running rough for invasive methods manuals, using machete and Scythe. Soils were sampled between May and July 2011.

Over these areas, seventy-square-meter meshes were established and soil samples were collected at mesh crossing-points, with regular spacing of each 10 meters, making 64 sampling points by mesh (Figure 1). These points were georeferenced using a Garmin 'Etrex' GPS receiver (South American'69). Next, soil sampling at 0.0-0.2 and $0.4-0.6 \mathrm{~m}$ for determination of granulometric and chemical attributes, totaling 128 soil samples in each mesh. Particle size characterization of the samples are shown in Table1. 
Table 1. Granulometric Analyzes (g.kg $\mathrm{kg}^{-1}$ ) for sugar cane and agroforestry in Humaitá, AM.

\begin{tabular}{cccccc}
\hline Clay & Silt & Sand & Clay & Silt & Sand \\
\hline & Depth $0.0-0.2 \mathrm{~m}$ & \multicolumn{5}{c}{ Depth 0.4-0.6 m } \\
\hline \multirow{7}{*}{284.94} & 474.49 & 240.57 & Cane 323.27 & 467.70 & 209.02 \\
\hline \multirow{7}{c}{ Agroforestry } \\
284.94 & 230.11 & 220.79 & 510.89 & 284.77 & 204.33 \\
\hline
\end{tabular}

The chemical elements and values were extracted by the following techniques: exchangeable calcium, magnesium and aluminum by $\mathrm{KCl}$; available phosphorus and potassium by Mehlich-1; potential acidity $(\mathrm{H}+\mathrm{Al})$ by buffered solution of calcium acetate at pH 7.0 (EMBRAPA, 1997). Based on the results of this chemical analysis, it was calculated the sum of bases (SB), cation exchange capacity (CEC) and base saturation (V\%).

The $\mathrm{pH}$ was determined potentiometrically using a 1: 2.5 soil and water ratio. Total carbon was determined by Walkley-Black method, which Yeomans and Bremner (1988) changes; and organic matter content, in turn, was estimated based on organic carbon.

Particle size analysis was performed by the pipette method using a $0.1 \mathrm{~mol} \mathrm{~L}-1 \mathrm{NaOH}$ solution as a chemical dispersant and mechanical shaking at high speed for $15 \mathrm{~min}$ as proposed by Embrapa (1997).

Factors were analyzed to relate a set of variables to be explained in terms of a limited number of new variables. We chose to use the principal component extraction (JEFFERS, 1978), which is calculated from the correlation matrix between variables. To facilitate interpretation, we used the method called orthogonal varimax rotation (HOFFMANN, 1992).

Factor analysis was complemented by a principal component analysis (PCA) to obtain a smaller set of linear combinations of the selected variables to analyze factors that have preserved most of the information provided by the original variables (SILVA et al., 2010) . This analysis makes it possible to assess how attributes interact qualitatively at the same time, whose original values were normalized to a mean of zero and variance equals to one to compose variables used in PCA. Components were selected by their eigenvalues, which had to be above 1.00 and be able to synthesize a cumulative variance above $70 \%$ (HAIR et al, 2005).

After data collection, we performed exploratory data analysis, calculating means, median, variance, coefficients of variation, skewness and kurtosis and normality test. The coefficient of variation (CV) was calculated as proposed by Warrick and Nielsen (1980), who classified it as low $(\mathrm{CV}<12 \%)$, medium (from $12 \%$ to $60 \%)$ and high $(\mathrm{CV}>60 \%)$. The data normality hypothesis was tested using the KolmogorovSmirnov test through the Minitab 14 statistical software (Minitab, 2000).

Spatial variability characterization was made through geostatistics (ISAAKS and SRIVASTAVA 1989). On basis of intrinsic hypothesis theory, the experimental semivariogram was estimated by the following Equation (1):

$$
\hat{\gamma}(h)=\frac{1}{2 N(h)} \sum_{i=1}^{N(h)}\left[Z\left(x_{i}\right)-Z\left(x_{i}+h\right)\right]^{2}
$$

wherein:

$\gamma(\mathrm{h})$ - semivariance value for sample sites separated by an $\boldsymbol{h}$ distance;

$\mathrm{N}(\mathrm{h})$ - number of pairs involved in semivariance calculation;

$\mathrm{Z}(\mathrm{xi})$ - value of $\mathrm{Z}$ attribute at $\boldsymbol{x i}$ site;

$\mathrm{Z}(\mathrm{xi}+\mathrm{h})$ - value of $\mathrm{Z}$ attribute separated by an $\boldsymbol{h}$ distance from $x \boldsymbol{i}$ site.

From a mathematical model fit to the calculated values of $\gamma(\mathrm{h})$, the theoretical model coefficients are set for the semivariogram (nugget effect, $\mathrm{C}_{0}$; structural variance, $\mathrm{C}_{1}$; sill, $\mathrm{C}_{0}+\mathrm{C}_{1}$; and range, a). The nugget effect is the semivariance value at zero distance and represents random variation component; sill is the semivariance value in which the curve is steady at a constant value; range is the distance from origin up to where sill reaches stable values, expressing distances beyond those in which samples are correlated (VIEIRA et al., 1983; TRANGMAR et al., 1985). In spatial dependence determination, we used the semivariogram exam through the $\mathrm{GS}^{+}$software (ROBERTSON, 1998). In case of doubt among more than one model for the same semivariogram, it was considered the best $\mathrm{R}^{2}$ (coefficient of determination).

In the spatial dependence analysis of variables under study, we used the classification proposed by Cambardella et al., (1994), in which $\left[\left(\mathrm{C}_{0} /\left(\mathrm{C}_{0}+\mathrm{C}_{1}\right)\right]\right.$ values lower than $25 \%$ are considered strong, between 25 and $75 \%$ indicate moderate and higher than $75 \%$ poor spatial dependence. 


\section{RESULTS AND DISCUSSION}

Based on knowledge of the variation of chemical attributes variation among management systems, we performed a factor analysis (Table 2).
This procedure helped in selecting attributes that had greater factor load by varimax method, wherein, it can be established which attributes had discriminatory power in common to the studied managements.

Table 2. Factors extracted by principal component analysis, emphasizing chemical attributes of factor load above 0.7 (module) for the studied managements in Humaitá - AM, Brazil.

\begin{tabular}{lcccc}
\hline \multirow{2}{*}{ Attributes } & \multicolumn{2}{c}{ Depth $\mathbf{0 - 2 0}$ cm } & \multicolumn{2}{c}{ Depth 20-40 cm } \\
\cline { 2 - 5 } $\mathrm{pH} \mathrm{H}_{2} \mathrm{O}$ & Factor 1 & Factor 2 & Factor 1 & Factor 2 \\
Potential acidity & 0,650232 & 0,739210 & $-0,832283$ & 0,316645 \\
Organic matter & $-0,565528$ & $-0,787364$ & $-0,962788$ & $-0,024864$ \\
Organic Carbon & 0,958053 & 0,137539 & 0,383626 & $-0,916440$ \\
Phosphorus & 0,958053 & 0,137539 & $-0,440249$ & $-0,894126$ \\
Potassium & 0,185738 & $-0,885345$ & $-0,256506$ & 0,088058 \\
Calcium & $-0,361017$ & $-0,788535$ & $-0,987312$ & 0,107913 \\
Magnesium & 0,720740 & 0,668949 & 0,631169 & 0,559974 \\
Base sum & 0,741923 & 0,612555 & $-0,789116$ & 0,503560 \\
Cation exchange capacity & 0,737543 & 0,640165 & 0,903290 & 0,242212 \\
Base saturation & $-0,508118$ & $-0,797619$ & 0,971143 & 0,115700 \\
\hline Eigenvalue s & 0,674863 & 0,707977 & 0,879777 & 0,205028 \\
\% Total variance & 8,627062 & 1,423419 & 7,148572 & 2,454421 \\
Cumulative eigenvalue & 78,42783 & 12,94017 & 64,98702 & 22,31292 \\
$\%$ Cumulative & 8,62706 & 10,05048 & 7,14857 & 9,60299 \\
\hline
\end{tabular}

In the factor analysis it was found that the first two factors in the depth of $0-20 \mathrm{~cm}$ explained altogether $91.30 \%$ of the total variance of the data and showed that all attributes showed high factor loadings. $\mathrm{OM}, \mathrm{CB}, \mathrm{Ca}, \mathrm{Mg}$, and $\mathrm{BS}$ are the most important attributes for the determination of Factor 1 which explains $78.42 \%$ of the total variance. The $\mathrm{pH}, \mathrm{H}+\mathrm{Al}, \mathrm{P}, \mathrm{K}, \mathrm{CEC}$ and $\mathrm{BS}$ is related to Factor 2, which explained $12.94 \%$ of the variance. In the depth of $20-40 \mathrm{~cm}$ explained as a whole $87.30 \%$ of the total variance of the data and showed that all attributes the exception of $\mathrm{P}$ and $\mathrm{Ca}$ showed high factor loadings. The $\mathrm{pH} \mathrm{H}+\mathrm{Al}, \mathrm{K}, \mathrm{Mg}, \mathrm{CEC}$ and BS attributes are the most important factor for determining the one that explained $64.98 \%$ of the total variance. The $\mathrm{OM}$ and $\mathrm{OC}$ is related to Factor 2 , which explained $22.31 \%$ of the variance.

Principal component analysis (PCA) was performed using high discriminatory-power variables (Figure 2 and 3). Using the ACP from the selected data in the $0-20 \mathrm{~cm}$ depth (Figure 2), it was possible to explain $91.36 \%$ of the total variance in the first two components (CP1 and CP2) and evaluate the interaction of attributes with the studied management.

A OC, OM, BS, V\%, Ca, $\mathrm{Mg}$ e $\mathrm{pH}$ related to sugarcane occurs due to the continuous application of limestone and fertilizers that contribute to an increase of base content and the straw the contribution of sugarcane. It indicates that perhaps these attributes are the most sensitive to changes and, therefore better able to reflect local balance alterations than other attributes. This way, they can be considered indicators of environmental changes. The attributes $\mathrm{P}, \mathrm{K}, \mathrm{CTC}$ and $\mathrm{H}+\mathrm{Al}$ are directly related to agroforestry environment. In agroforest, $\mathrm{CEC}$ and $\mathrm{H}+\mathrm{Al}$ attributes are linked to organic material and plant waste decomposition, which forms water-soluble organic complexes of $\mathrm{Ca}$ and $\mathrm{Mg}$ with organic binders (MIYAZAWA et al., 1993), facilitating leaching of cations along the soil profile.

In the $20-40 \mathrm{~cm}$ depth, it was possible to explain $89.21 \%$ of the total variance in the first two components (CP1 and CP2), Figure 3, and evaluate the interaction of attributes with the studied management. The variables $\mathrm{H}+\mathrm{Al}, \mathrm{CTC}, \mathrm{K}, \mathrm{OC}$, $\mathrm{OM}$ are related to the development environment, while the variables $\mathrm{pH}, \mathrm{Mg}, \mathrm{SB}$ and $\mathrm{V} \%$ are related to the environment of sugar cane similar to that observed in depth of $0-20 \mathrm{~cm}$. 


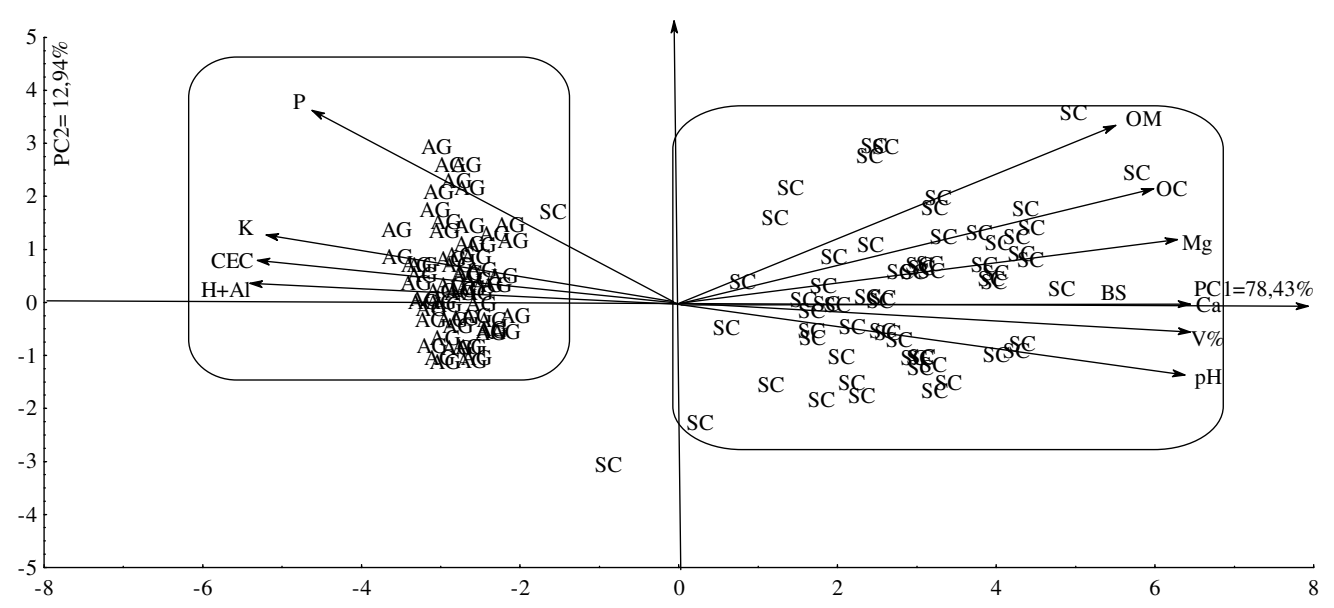

Figure 2. Principal component analysis (PCA) of soil chemical attributes with high discriminatory power for the studied managements in Humaitá County - AM, Brazil in deph 0-20 cm. SC= sugarcane; AG= agroforestry; $\mathrm{Ca}=$ calcium; $\mathrm{Mg}=$ magnesium, $\mathrm{P}=$ Phosphorus ; $\mathrm{K}=$ Potassium; OM= Organic matter; $\mathrm{OC}=$ Carbon Organic; $\mathrm{BS}=$ base sum; $\mathrm{CEC}=$ cation exchange capacity; $\mathrm{V} \%$ = base saturation; $\mathrm{pH}$; $\mathrm{H}+\mathrm{Al}=$ Potential acidity.

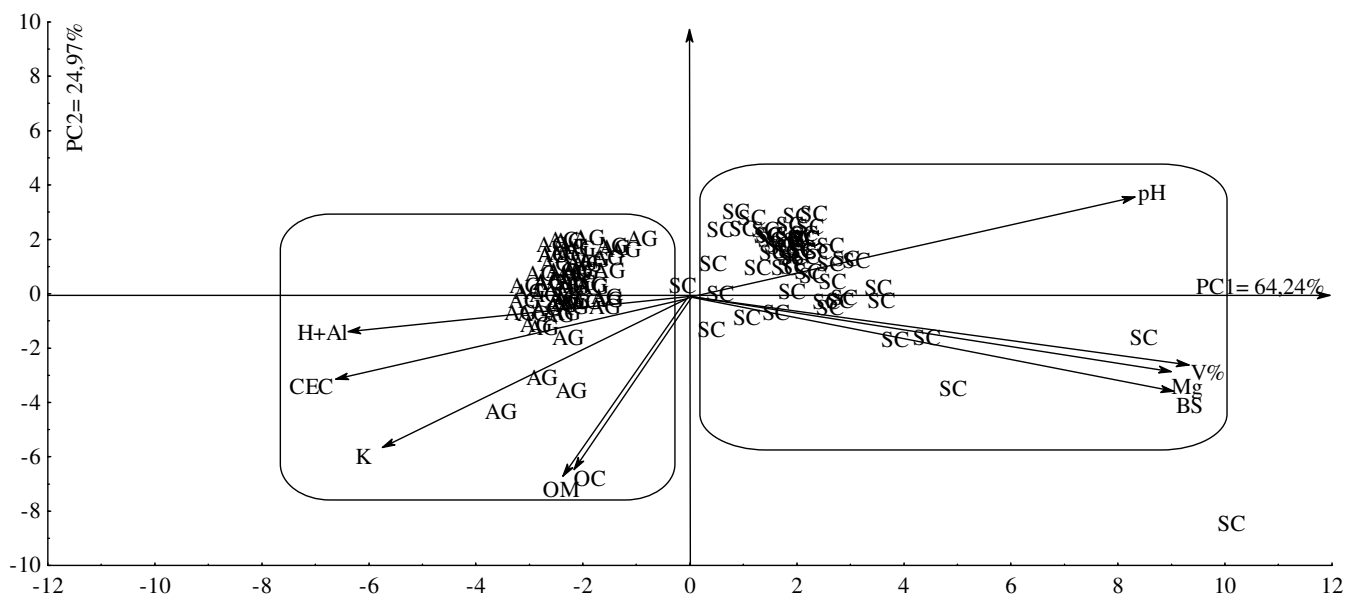

Figure 3. Principal component analysis (PCA) of soil chemical attributes with high discriminatory power for the studied managements in Humaitá County - AM, Brazil in deph 20-40 cm. SC= sugarcane; AG= agroforestry; $\mathrm{Ca}=$ calcium; $\mathrm{Mg}=$ magnesium, $\mathrm{P}=$ Phosphorus ; $\mathrm{K}=$ Potassium; $\mathrm{OM}=$ Organic matter; $\mathrm{OC}=$ Carbon Organic; $\mathrm{BS}=$ base sum; $\mathrm{CEC}=$ cation exchange capacity; $\mathrm{V} \%$ = base saturation; $\mathrm{pH}$; $\mathrm{H}+\mathrm{Al}=$ Potential acidity.

Chemical data frequency distribution in soil was evaluated using descriptive statistics, and it showed values close to mean and median of almost all studied variables. This fact demonstrate a distribution near to normal, which is justified by skewness and kurtosis values near to zero (Table 3 and 4).

Some data had no symmetric distribution, since they have mean and median values somewhat remote. This indicates influence by extreme values, being $\mathrm{Ca}, \mathrm{Mg}$, BS (0.0-0.2 and 0.4-0.6 m) and $\mathrm{V} \%$ (0.4-0.6 m) in agroforestry area (Table 3); $\mathrm{H}+\mathrm{Al}$ and
CEC (0.0-0.2 m); H+Al, OM, Mg, BS, CEC and $\mathrm{V} \%$ (0.4-0.6 m) in sugarcane area (Table 3). Consequently, it can be observed kurtosis and skewness values farther away from zero, which confirms the fact that these variables did not follow the pattern of this distribution curve being non symmetric. According to Silva (2010), the skewness coefficient is used to characterize how and how much the frequency distribution deviates from symmetry, if $\mathrm{Cs}>0$, there is a right asymmetrical distribution; $\mathrm{Cs}<0$, there is a left asymmetrical distribution; and when $\mathrm{Cs}=0$, the distribution is 
symmetrical. Cortez et al., (2011) claim that as the asymmetry and kurtoses values are closer to zero, the greater the normality of the data. Therefore, the information of these parameters makes the adjustment "by feeling" of the semivariogram.

Table 3. Descriptive statistics of chemical attributes in area of agroforestry's in Humaitá, AM.

\begin{tabular}{|c|c|c|c|c|c|c|c|c|c|c|c|}
\hline \multirow{3}{*}{ Attributes } & \multicolumn{11}{|c|}{ Descriptive statistics } \\
\hline & Unit & Mean & Median & Mín & Máx & SD & Var. & CV\% & Kurtosis & Skew. & $\mathrm{d}$ \\
\hline & \multicolumn{11}{|c|}{ Depth $0.0-0.2 \mathrm{~m}$} \\
\hline \multirow{2}{*}{$\begin{array}{l}\mathrm{pH} \\
\mathrm{H}+\mathrm{Al}\end{array}$} & $\mathrm{H}_{2} \mathrm{O}$ & 3.78 & 3.80 & 3.60 & 3.90 & 0.06 & 0.00 & 1.53 & 0.80 & -0.48 & $0.06^{\text {ns }}$ \\
\hline & $\underset{1}{\operatorname{mmol}} \mathrm{kg}^{-}$ & 189.52 & 185.00 & 150.00 & 228.00 & 17.54 & 307.78 & 9.26 & -0.48 & -0.51 & $0.05^{\mathrm{ns}}$ \\
\hline OM & $\mathrm{g}, \mathrm{dm}^{-3}$ & 20.58 & 20.50 & 14.00 & 30.00 & 3.19 & 10.15 & 15.48 & 0.63 & 0.79 & $0.09^{\mathrm{ns}}$ \\
\hline $\mathrm{P}$ & $\mathrm{mg} \mathrm{dm}^{-3}$ & 8.19 & 8.00 & 6.00 & 13.00 & 1.55 & 2.41 & 18.96 & 0.39 & 0.57 & $0.04^{\mathrm{ns}}$ \\
\hline K & $\underset{1}{\mathrm{mmol} \mathrm{kg}}$ & 1.11 & 1.10 & 0.60 & 1.80 & 0.24 & 0.06 & 21.78 & 0.76 & 0.59 & $0.07^{\mathrm{ns}}$ \\
\hline $\mathrm{Ca}$ & $\underset{1}{\mathrm{mmol}} \mathrm{kg}^{-}$ & 2.39 & 2.00 & 2.00 & 4.00 & 0.55 & 0.31 & 23.11 & 0.09 & 1.03 & $0.09^{\mathrm{ns}}$ \\
\hline $\mathrm{Mg}$ & $\underset{1}{\mathrm{mmol}} \mathrm{kg}^{-}$ & 1.36 & 1.00 & 1.00 & 2.00 & 0.48 & 0.23 & 35.58 & -1.69 & 0.60 & $0.10^{\mathrm{ns}}$ \\
\hline BS & $\underset{1}{\mathrm{mmol}} \mathrm{kg}^{-}$ & 4.86 & 4.15 & 3.60 & 7.40 & 1.15 & 1.33 & 23.73 & -1.29 & 0.67 & $0.28^{*}$ \\
\hline CEC & $\mathrm{mmol} \mathrm{kg}_{1}^{-}$ & 194.37 & 191.40 & 154.70 & 232.10 & 17.45 & 304.44 & 8.98 & -0.54 & -0.51 & $0.24 *$ \\
\hline \multirow[t]{2}{*}{$\mathrm{V}$} & $\%$ & 2.52 & 2.20 & 1.77 & 4.03 & 0.66 & 0.44 & 26.24 & -0.80 & 0.75 & $0.18 *$ \\
\hline & \multicolumn{11}{|c|}{ Depth $0.4-0.6 \mathrm{~m}$} \\
\hline$\overline{\mathrm{pH}}$ & $\mathrm{H}_{2} \mathrm{O}$ & 3.81 & 3.80 & 3.70 & 3.90 & 0.05 & 0.002 & 1.23 & 1.74 & 0.23 & $0.06^{\mathrm{ns}}$ \\
\hline $\mathrm{H}+\mathrm{Al}$ & $\underset{1}{\mathrm{mmol} \mathrm{kg}}$ & 211.86 & 205.00 & 166.00 & 253.00 & 18.64 & 347.36 & 8.80 & -0.81 & -0.40 & $0.06^{\mathrm{ns}}$ \\
\hline $\mathrm{OM}$ & $\mathrm{g} \mathrm{dm}^{-3}$ & 10.66 & 10.50 & 7.00 & 19.00 & 2.39 & 5.69 & 22.38 & 1.81 & 1.02 & $0.06^{\mathrm{ns}}$ \\
\hline K & $\underset{1}{\operatorname{mmol}} \mathrm{kg}$ & 0.64 & 0.60 & 0.40 & 1.00 & 0.10 & 0.01 & 16.43 & 2.48 & 0.95 & $0.06^{\mathrm{ns}}$ \\
\hline $\mathrm{Mg}$ & $\underset{1}{\mathrm{mmol}_{\mathrm{kg}}}$ & 1.02 & 1.00 & 1.00 & 2.00 & 0.13 & 0.02 & 12.31 & 64.00 & 8.00 & $0.05^{\mathrm{ns}}$ \\
\hline BS & $\underset{1}{\operatorname{mmol}} \mathrm{kg}^{-}$ & 2.84 & 2.60 & 2.40 & 5.70 & 0.55 & 0.30 & 19.20 & 11.34 & 2.96 & $0.32 *$ \\
\hline CEC & $\underset{1}{\mathrm{mmol}} \mathrm{kg}^{-}$ & 214.70 & 208.75 & 168.50 & 255.60 & 18.80 & 353.57 & 8.76 & -0.84 & -0.41 & $0.27 *$ \\
\hline $\mathrm{V}$ & $\%$ & 1.33 & 1.25 & 1.02 & 2.44 & 0.23 & 0.05 & 17.30 & 7.77 & 2.16 & $0.11 *$ \\
\hline
\end{tabular}

Table 4. Descriptive statistics of chemical attributes in area of sugar cane in Humaitá, AM.

\begin{tabular}{|c|c|c|c|c|c|c|c|c|c|c|c|}
\hline \multirow{3}{*}{$\begin{array}{l}\text { Attribut } \\
\text { s }\end{array}$} & \multicolumn{11}{|c|}{ Descriptive statistics } \\
\hline & ute Unit & Mean & Median & Mín & Máx & SD & Var. & $\mathrm{CV} \%$ & $\begin{array}{c}\text { Kurtos } \\
\text { is }\end{array}$ & Skew. & d \\
\hline & \multicolumn{11}{|c|}{ Depth $0.0-0.2 \mathrm{~m}$} \\
\hline $\mathrm{pH}$ & $\mathrm{H}_{2} \mathrm{O}$ & 4.43 & 4.50 & 3.90 & 4.70 & 0.15 & 0.02 & 3.39 & 1.07 & -0.85 & $0.05^{\mathrm{ns}}$ \\
\hline $\mathrm{H}+\mathrm{Al}$ & $\mathrm{mmol} \mathrm{kg}{ }^{-1}$ & 89.64 & 80.00 & 64.00 & 205.00 & 21.09 & 444.68 & 23.52 & 13.43 & 2.96 & $0.15 *$ \\
\hline $\mathrm{OM}$ & $\mathrm{g}, \mathrm{dm}^{-3}$ & 30.48 & 30.50 & 11.00 & 47.00 & 6.25 & 39.11 & 20.52 & 1.01 & -0.05 & $0.07^{\mathrm{ns}}$ \\
\hline $\mathrm{P}$ & $\mathrm{mg} \mathrm{dm}$ & 6.36 & 7.00 & 3.00 & 10.00 & 1.57 & 2.46 & 24.64 & -0.60 & -0.06 & $0.04^{\mathrm{ns}}$ \\
\hline K & $\mathrm{mmol} \mathrm{kg}$ & 0.49 & 0.50 & 0.30 & 0.70 & 0.11 & 0.01 & 22.98 & -0.77 & 0.02 & $0.04^{\mathrm{ns}}$ \\
\hline $\mathrm{Ca}$ & $\mathrm{mmol} \mathrm{kg}{ }^{-1}$ & 14.58 & 15.00 & 4.00 & 27.00 & 4.17 & 17.42 & 28.63 & 0.41 & 0.07 & $0.03^{\mathrm{ns}}$ \\
\hline $\mathrm{Mg}$ & $\mathrm{mmol} \mathrm{kg}{ }^{-1}$ & 8.06 & 8.00 & 3.00 & 16.00 & 2.84 & 8.06 & 35.21 & 0.32 & 0.75 & $0.07^{\mathrm{ns}}$ \\
\hline
\end{tabular}




\begin{tabular}{lcccccccccccc}
$\mathrm{BS}$ & $\mathrm{mmol} \mathrm{kg}^{-1}$ & 23.13 & 23.30 & 7.40 & 43.60 & 6.92 & 47.85 & 29.90 & 0.23 & 0.33 & $0.06^{\mathrm{ns}}$ \\
$\mathrm{CEC}$ & $\mathrm{mmol} \mathrm{kg}^{-1}$ & 112.77 & 107.50 & 91.60 & 216.70 & 18.35 & 336.85 & 16.27 & 15.77 & 3.30 & $0.19^{*}$ \\
$\mathrm{~V}$ & $\%$ & 21.06 & 21.6 & 5.4 & 35.3 & 6.83 & 46.70 & 32.44 & -0.45 & -0.12 & $0.05^{*}$ \\
\hline \multicolumn{10}{c}{} & \multicolumn{8}{c}{ Depth } & $0.4-0.6 \mathrm{~m}$ \\
\hline $\mathrm{pH}$ & $\mathrm{H}_{2} \mathrm{O}$ & 4.06 & 4.10 & 3.90 & 4.30 & 0.07 & 0.01 & 1.75 & 2.77 & 0.82 & $0.08^{\text {ns }}$ \\
$\mathrm{H}+\mathrm{Al}$ & $\mathrm{mmol} \mathrm{kg}^{-1}$ & 126.66 & 121.00 & 80.00 & 185.00 & 19.44 & 378.10 & 15.35 & 2.86 & 1.03 & $0.10^{\text {ns }}$ \\
$\mathrm{OM}$ & $\mathrm{g} \mathrm{dm}^{-3}$ & 8.69 & 8.00 & 5.00 & 20.00 & 2.48 & 6.15 & 28.56 & 5.94 & 1.97 & $0.14^{*}$ \\
$\mathrm{~K}$ & $\mathrm{mmol} \mathrm{kg}^{-1}$ & 0.40 & 0.40 & 0.20 & 0.60 & 0.09 & 0.01 & 23.31 & 0.46 & 0.31 & $0.03^{\text {ns }}$ \\
$\mathrm{Mg}$ & $\mathrm{mmol} \mathrm{kg}^{-1}$ & 2.16 & 2.00 & 1.00 & 7.00 & 0.98 & 0.96 & 45.42 & 12.19 & 3.02 & $0.10^{\text {ns }}$ \\
$\mathrm{BS}$ & $\mathrm{mmol} \mathrm{kg}^{-1}$ & 6.18 & 5.40 & 3.30 & 19.50 & 2.48 & 6.16 & 40.16 & 14.35 & 3.40 & $0.30^{*}$ \\
$\mathrm{CEC}$ & $\mathrm{mmol} \mathrm{kg}^{-1}$ & 132.83 & 126.40 & 94.50 & 190.50 & 18.52 & 342.82 & 13.94 & 2.95 & 1.42 & $0.23^{*}$ \\
$\mathrm{~V} \%$ & $\%$ & 4.83 & 4.27 & 2.65 & 19.60 & 2.64 & 6.99 & 54.72 & 18.49 & 3.96 & $0.26^{\text {ns }}$ \\
\hline
\end{tabular}

Min.= Minimum; Max.= Maximum; SD = Standard deviation; Var. = Variance; $C V=$ Coefficient of variation; Skew.= Skewness; $d=$ normality test, * significant by the Kolmogorov-Smirnov test $(\mathrm{p} \leq 0,05)$.

Regarding the chemical attribute mean values for both areas (agroforestry and canesugar), it can be observed different values for both attributes (Table 3 and 4). The agroforestry had higher values for the area under sugarcane. However, higher CEC values for agroforestry area are observed, with 194.37 and $214.70 \mathrm{mmol} / \mathrm{kg}$ at 0.0-0.2 and 0.4-0.6 depths, respectively. Such fact may be due to the strong influence of potential acidity $(\mathrm{H}+\mathrm{Al})$ with 189.52 and $211.86 \mathrm{mmol} / \mathrm{kg}$ at 0.0-0.2 $\mathrm{m}$ and 0.4-0.6 $\mathrm{m}$ depths, respectively. In contrast, sugarcane presented CEC values of 112.77 and $132.63 \mathrm{mmol} / \mathrm{kg}$ at $0.0-0.2 \mathrm{~m}$ and $0.4-0.6 \mathrm{~m}$ depths, respectively, which were less influenced by potential acidity that showed values of 89.64 and $126.66 \mathrm{mmol} / \mathrm{kg}$ at both respective depths.

Considering the coefficient of variation limits proposed by Warrick and Nielsen (1980), pH, $\mathrm{H}+\mathrm{Al}$ and $\mathrm{CEC}$ (at $0.0-0.2$ and $0.4-0.6 \mathrm{~m}$ depths) only for agroforestry and singly $\mathrm{pH}$ (at $0.0-0.2$ and $0.4-0.6 \mathrm{~m}$ depths) for sugarcane presented low coefficients $(\mathrm{CV}<12 \%)$, which is an indicative of low variability. $\mathrm{Mg}$ and $\mathrm{V} \%$ (at $0.0-0.2 \mathrm{~m}$ depth) and $\mathrm{P}, \mathrm{Ca}, \mathrm{Mg}, \mathrm{BS}$ and $\mathrm{V} \%$ (at $0.0-0.2 \mathrm{~m}$ depth); $\mathrm{OM}, \mathrm{Mg}$, BS and V\% (0.4-0.6 m depth) in grazing area presented high $\mathrm{CV}(\mathrm{CV}>24.1 \%)$. The other variables presented moderate $\mathrm{CV}$ for both environments $(\mathrm{CV}>12.1 \%<24 \%)$. In this way, it is observed a greater predominance of moderate variability in the chemical attributes for both agroforestry and sugarcane, what demonstrate moderate to high heterogeneity of such attributes.

As stated by Camargo et al., (2008), the CV enables to compare variability between samples of different unit variables; however, it does not aid in the analysis of spatial variability of soil attributes neither the spatial pattern. Therefore, attribute variability encountered in our study can justify spatial dependence, what make easy to understand their occurrence pattern. Carvalho et al., (2003) asserted that results of soil attribute analysis are used to present high coefficient of variation values.

It was observed normality by KolmogorovSmirnov test for the attributes BS, CEC and V\% at both depths in agroforestry. Likewise in sugarcane $\mathrm{H}+\mathrm{Al}, \mathrm{CEC}$, V\% at 0.0-0.2 m depth and OM, BS and $\mathrm{CEC}$ at $0.4-0.6 \mathrm{~m}$. However, the other variables did not present data normality in any area.

The evaluated attributes undergone to semivariogram application to analyze their spatial dependence. Tables 4 and 5 show the semivariogram parameters. There was an exponential model fit for $\mathrm{H}+\mathrm{Al}(0.0-0.2 \mathrm{~m}), \mathrm{pH}$ and $\mathrm{OM}(0.4-0.6 \mathrm{~m})$. In addition, $\mathrm{P}$ and CEC (0.0 $0.2 \mathrm{~m}$ ) and $\mathrm{H}+\mathrm{Al}, \mathrm{Mg}, \mathrm{BS}, \mathrm{CEC}, \mathrm{V} \%$ (0.4 - $0.6 \mathrm{~m})$ were fit to the spherical model. For the other variables, there was no fit to any model (Table 5).

When the studied variable is spatially independent, the $\mathrm{C}_{0}$ (nugget effect) is equal to the $\mathrm{C}_{1}+\mathrm{C}_{0}$ (sill), which is known as a pure nugget effect (PNE). PNE is important and indicates random distribution, i.e., unexplained variability or undetected variation, and it may occur due to measurement, sampling errors or non-detected micro-variation, considering the used sampling space greater than required to detect spatial dependence (CAMBARDELLA et al., 1994).

In sugarcane area, there was spherical and exponential model fit, with predominance of spherical at 0.00 to $0.20 \mathrm{~m}$ depth; inversely, at 0.4 $0.6 \mathrm{~m}$ depth, the exponential model was bet fit (Table 6). 
Tabela 5. Models and parameters estimated semivariogram of the chemical attributes in agroforestry area in Humaitá AM.

\begin{tabular}{|c|c|c|c|c|c|c|c|}
\hline \multirow{3}{*}{ Attributes } & \multicolumn{7}{|c|}{ Geoestatistics } \\
\hline & Unit & Model & $\mathrm{NE}\left(\mathrm{C}_{0}\right)$ & $\begin{array}{c}\text { Sill } \\
\left(\mathrm{C}_{0}+\mathrm{C}_{1}\right) \\
\end{array}$ & $\begin{array}{l}\text { Reach } \\
\text { (a) }\end{array}$ & $\mathrm{R}^{2}$ & DSD \\
\hline & \multicolumn{7}{|c|}{ Depth $0.0-0.2 \mathrm{~m}$} \\
\hline $\mathrm{pH}$ & $\mathrm{H}_{2} \mathrm{O}$ & PNE & - & - & - & - & - \\
\hline $\mathrm{H}+\mathrm{Al}$ & mmol kg-1 & Exp. & 3.9E-004 & 7.1E-003 & 45.60 & 0.77 & 0.94 \\
\hline MO & $\mathrm{g} \mathrm{dm}^{-3}$ & PNE & - & - & - & - & - \\
\hline $\mathrm{P}$ & $\mathrm{mg} \mathrm{dm}^{-3}$ & Sph. & 0.08 & 2.47 & 84.64 & 0.95 & 0.96 \\
\hline K & $\mathrm{mmol} \mathrm{kg}{ }^{-1}$ & PNE & - & - & - & - & - \\
\hline $\mathrm{Ca}$ & $m m o l ~ \mathrm{~kg}^{-1}$ & PNE & - & - & - & - & - \\
\hline $\mathrm{Mg}$ & $m m o l ~ \mathrm{~kg}^{-1}$ & PNE & - & - & - & - & - \\
\hline $\mathrm{BS}$ & $m m o l ~ \mathrm{~kg}^{-1}$ & PNE & - & - & - & - & - \\
\hline CEC & $m m o l ~ \mathrm{~kg}^{-1}$ & Sph. & 93.70 & 282.30 & 52.50 & 0.96 & 0.67 \\
\hline \multirow[t]{2}{*}{$\mathrm{V}$} & $\%$ & PNE & - & - & - & - & - \\
\hline & \multicolumn{7}{|c|}{ Depth $0.4-0.6 \mathrm{~m}$} \\
\hline $\mathrm{pH}$ & $\mathrm{H}_{2} \mathrm{O}$ & Exp. & $1.18^{-004}$ & $2.99^{-00,3}$ & 37.60 & 0.82 & 0.60 \\
\hline $\mathrm{H}+\mathrm{Al}$ & $\mathrm{mmol} \mathrm{kg}{ }^{-1}$ & Sph. & 14.14 & 371.80 & 66.58 & 0.94 & 0.96 \\
\hline MO & $\mathrm{g} \mathrm{dm}^{-3}$ & Exp. & 0.30 & 5.70 & 29.10 & 0.74 & 0.94 \\
\hline K & $\mathrm{mmol} \mathrm{kg}{ }^{-1}$ & PNE & - & - & - & - & - \\
\hline $\mathrm{Mg}$ & mmol kg & Sph. & 0.001 & 0.02 & 54.00 & 1.00 & 0.90 \\
\hline BS & $\mathrm{mmol} \mathrm{kg}$ & Sph. & 0.13 & 0.20 & 44.75 & 0.88 & 0.34 \\
\hline CEC & $\mathrm{mmol} \mathrm{kg}$ & Sph. & 9.31 & 382.73 & 68.17 & 0.95 & 0.97 \\
\hline $\mathrm{V}$ & $\%$ & Sph. & 0.001 & 0.03 & 19.80 & 0.69 & 0.94 \\
\hline
\end{tabular}

$\mathrm{C}_{0}=$ Nugget Effect $\mathrm{C}_{0}+\mathrm{C}_{1}=$ Sill; DSD: degree of spatial dependence; $\mathrm{R}^{2}=$ Coefficient of Determination; Exp = exponential; Sph = spherical; $\mathrm{PNE}=$ pure nugget effect.

Tabela 6. Models and parameters estimated semivariogram of the chemical attributes in cane area in Humaitá AM.

\begin{tabular}{|c|c|c|c|c|c|c|c|}
\hline \multirow{3}{*}{ Attributes } & \multicolumn{3}{|c|}{ Estatística } & \multirow[b]{2}{*}{$C_{0}+C_{1}$} & \multirow[b]{2}{*}{$a(\mathrm{~m})$} & \multirow[b]{2}{*}{$\mathrm{R}^{2}$} & \multirow[b]{2}{*}{$\mathrm{DSD}$} \\
\hline & Unit & Modelo & $C_{0}$ & & & & \\
\hline & \multicolumn{7}{|c|}{ Depth $0.0-0.2 \mathrm{~m}$} \\
\hline $\mathrm{pH}$ & $\mathrm{H}_{2} \mathrm{O}$ & Sph. & 0.00 & 0.01 & 17.40 & 0.83 & 0.77 \\
\hline $\mathrm{H}+\mathrm{Al}$ & $\mathrm{mmol} \mathrm{kg}{ }^{-1}$ & Exp. & 40.20 & 205.02 & 23.35 & 0.81 & 0.80 \\
\hline MO & $\mathrm{g} \mathrm{dm}^{-3}$ & Exp. & 8.11 & 40.40 & 26.10 & 0.97 & 0.79 \\
\hline $\mathrm{P}$ & $\mathrm{mg} \mathrm{dm}^{-3}$ & Sph. & 0.26 & 2.34 & 33.00 & 0.77 & 0.88 \\
\hline K & $\mathrm{mmol} \mathrm{kg}^{-1}$ & Sph. & 0.00 & 0.01 & 18.70 & 0.57 & 0.84 \\
\hline $\mathrm{Ca}$ & $\mathrm{mmol} \mathrm{kg}{ }^{-1}$ & Sph. & 2.43 & 13.08 & 15.70 & 0.59 & 0.81 \\
\hline $\mathrm{Mg}$ & $\mathrm{mmol} \mathrm{kg}{ }^{-1}$ & Sph. & 2.10 & 6.50 & 14.10 & 0.91 & 0.67 \\
\hline $\mathrm{BS}$ & $\mathrm{mmol} \mathrm{kg}{ }^{-1}$ & Sph. & 0.01 & 0.07 & 18.50 & 0.81 & 0.77 \\
\hline CEC & $\mathrm{mmol} \mathrm{kg}{ }^{-1}$ & $\operatorname{Exp}$ & 34.04 & 174.30 & 26.70 & 0.97 & 0.80 \\
\hline \multirow[t]{2}{*}{$\mathrm{V}$} & $\%$ & Sph. & 0.02 & 0.12 & 13.90 & 0.81 & 0.75 \\
\hline & \multicolumn{7}{|c|}{ Depth 0.4-0.6 m } \\
\hline $\mathrm{pH}$ & $\mathrm{H}_{2} \mathrm{O}$ & Exp. & 0.00 & 0.002 & 28.20 & 0.93 & 0.78 \\
\hline $\mathrm{H}+\mathrm{Al}$ & $\mathrm{mmol} \mathrm{kg}^{-1}$ & Exp. & 29.32 & 285.27 & 28.65 & 0.82 & 0.89 \\
\hline MO & $\mathrm{g}, \mathrm{dm}^{-3}$ & Exp. & 1.08 & 3.82 & 27.30 & 0.90 & 0.71 \\
\hline $\mathrm{K}$ & $\mathrm{mmol} \mathrm{kg}^{-1}$ & Sph. & 0.004 & 0.008 & 31.00 & 0.93 & 0.50 \\
\hline $\mathrm{Mg}$ & mmol kg ${ }^{-1}$ & Exp. & 0.07 & 0.22 & 47.40 & 0.98 & 0.82 \\
\hline $\mathrm{BS}$ & $\mathrm{mmol} \mathrm{kg}{ }^{-1}$ & Exp. & 0.26 & 1.35 & 21.60 & 0.92 & 0.80 \\
\hline CEC & mmol kg ${ }^{-1}$ & Exp. & 80.16 & 280.72 & 29.72 & 0.74 & 0.71 \\
\hline V & $\%$ & Sph. & 0.02 & 0.80 & 34.20 & 0.96 & 0.71 \\
\hline
\end{tabular}

$\mathrm{C}_{0}=$ Nugget Effect; $\mathrm{C}_{0}+\mathrm{C}_{1}=$ Sill; DSD: degree of spatial dependence; $\mathrm{R}^{2}=$ Coefficient of Determination; $\mathrm{Exp}=$ exponential; Sph $=$ spherical; $\mathrm{PNE}=$ pure nugget effect. 
It is observed a spherical model predominance of the chemical attributes in both areas, similarly to other authors' results (MONTANARI et al., 2008; CARVALHO et al., 2010). For Trangmar et al., (1985), Cambardella et al., (1994), Carvalho et al., (2003) and Cavalcante et al., (2007), spherical and exponential models are considered as the most common theoretical models for soil and plant properties.

The nugget effect $\left(\mathrm{C}_{0}\right)$ is a crucial parameter to be considered as it represents the unexplained or random variance, which is constantly caused by measurement errors or variations of attributes that cannot be detected at sampling scale (VIEIRA, 2000). The lower the rate between nugget effect and sill of the semivariogram, the greater the spatial dependence presented by the attribute. With this, the greater the phenomenon continuity, the lower the estimation variance and the greater the confidence in the estimated value. As suggested by Cambardella et al., (1994), the chemical properties were classified according to spatial dependence magnitude, taking into account the nugget effect.

In agroforestry area, $\mathrm{H}+\mathrm{Al}$ and $\mathrm{P}(0.0-0.2$ $\mathrm{m}), \mathrm{pH}$, and $\mathrm{BS}(0.4-0.6 \mathrm{~m})$ were classified as moderate DSD; however, the other variables were ranked as poor DSD for both depths. The same behavior is observed in sugarcane area, where we observed that only $\mathrm{Mg}$ and $\mathrm{V} \%(0.0-0.2 \mathrm{~m}), \mathrm{OM}$, $\mathrm{K}, \mathrm{CEC}$ and V\% (0.4 - $0.6 \mathrm{~m})$ were classified with moderate DSD, while the rest were weak. Some researches, such as Souza et al., (2006), and Campos et al., (2007) found an DSD range in sugarcane from strong to moderate.

The strong spatial dependence of soil attributes is commonly attributed to intrinsic factors, whereas extrinsic factors favor weak dependence (CAMBARDELLA et al., 1994). Thus, the moderate spatial dependence and weak would be due to soil homogenization from the different uses and management systems (CAVALCANTE et al., 2007).

An important parameter in semivariogram studies is the range. This parameter indicates the maximum distance at which the sampling points are correlated (VIEIRA et al., 1983), in other words, measurements performed at greater distances have randomized distribution, being therefore, independent from each other. It is an important measure for experimental planning and evaluation and may help to define sampling procedures with direct application in the sample plan.

It is noteworthy to mention that in agroforestry site, range values vary from $45.60 \mathrm{~m}$ to $84.64 \mathrm{~m}$ at first depth and from $19.80 \mathrm{~m}$ to $68.17 \mathrm{~m}$ at the second one. While in sugarcane area, these values range from $13.90 \mathrm{~m}$ to $33.00 \mathrm{~m}$ at 0.0 to 0.2 $\mathrm{m}$ depth and $21.30 \mathrm{~m}$ to $57.70 \mathrm{~m}$ at 0.4 to $0.6 \mathrm{~m}$. It was noticed that in agroforestry area, the range of values are much higher when compared to sugarcane, indicating a higher spatial continuity in this area. Therefore, beyond vertical variation, there is also variability among the horizontal depths for both areas, since range was different for the variables at the different evaluated depths.

\section{CONCLUSIONS}

In conclusion, our findings suggest that for most of the chemical attributes was observed spatial dependence in both areas, with DSD varying from weak to moderate, with prevalence of the weak one.

The multivariate analysis was efficient in the selection of chemical soil attributes that best represented the agroforestry environments and sugarcane.

The results of this study will serve as a basis for further studies on these environments and other systems within the region; moreover serving as a basis for agricultural planning aiming a better environmental sustainability.

\section{ACKNOWLEDGEMENTS}

The authors would like to thank the FAPEAM and SECTI-AM for financial support.

RESUMO: Existe uma carência de estudos enfocando o comportamento espacial de atributos químicos no Amazonas. Neste sentido o objetivo deste trabalho foi avaliar os atributos químicos do solo por meio de técnicas multivariadas e geoestatística em área com agrofloresta e cana-de-açúcar em Humaitá, AM, Brasil. O estudo foi realizado em uma propriedade rural em Humaitá, Amazonas. Nestas áreas foram estabelecidas malhas de 70,00 m x 70,00 m, com espaçamento regular de $10,00 \times 10,00 \mathrm{~m}$ totalizando 64 pontos e em seguida, coletadas amostras de solos na profundidade de 0,0-0,20 e 0,40 - 0,60 m. Foram determinados os atributos químicos (pH, MO, P, K, Ca, Mg, SB, CTC, V\% e H+Al). Utilizaram-se técnicas de estatística descritiva, multivariada e geoestatística. Em conclusão, nossos resultados sugerem que, para a maioria dos atributos químicos foi observada dependência espacial em ambas as áreas, com DSD variando de fraca a moderada, com prevalência de um fraco e a análise multivariada foi eficiente na seleção de atributos químicos do solo que melhor representou os ambientes de agrofloresta e cana de açúcar. 
PALAVRAS-CHAVE: Variabilidade espacial. Atributos do solo. Sul do Amazonas.

\section{REFERENCES}

AQUINO, R. E.; MARQUES JR, J.; CAMPOS, M. C. C.; OLIVEIRA, I. A.; SIQUEIRA, D. S. Distribuição espacial de atributos químicos do solo em área de pastagem e floresta. Pesquisa Agropecuária Tropical, Goiânia, v. 44, p. 32-41, 2014. http://dx.doi.org/10.1590/S1983-40632014000100001

BOTTEGA, E. L.; QUEIROZ, D. M.; PINTO, F. A. C.; SOUZA, C. M. A. Variabilidade espacial de atributos do solo em sistema de semeadura direta com rotação de culturas no cerrado brasileiro. Revista Ciência Agronômica, Fortaleza, v. 44, n. 1, p. 1-9, 2013. http://dx.doi.org/10.1590/S1806-66902013000100001

BURROUGH, P.A. Soil variability: a late 20th century view. Soils and Fertilizers, New York, v.56, n.5, p.529-562, 1993.

CAMARGO, L. A.; MARQUES JUNIOR, J.; PEREIRA, G. T.; HORVAT, R. A. Variabilidade espacial de atributos mineralógicos de um Latossolo sob diferentes formas do relevo. II - correlação espacial entre mineralogia e agregados. Revista Brasileira de Ciência do Solo, Viçosa, v.32, n.6, p.2279-2288, 2008.

CAMBARDELLA, C. A.; MOORMAN, T. B.; NOVAK, J. M.; PARKIN, T. B.; KARLEN, D. L.; TURCO, R. F.; KONOPKA, A. E. Field-scale variability of soil properties in Central Iowa. Soil Science Society America Journal, Madison, v.58, n.4, p.1501-1511, 1994.

http://dx.doi.org/10.2136/sssaj1994.03615995005800050033x

CAMPOS, M. C. C.; MARQUES JÚNIOR, J.; PEREIRA, G. T.; FREITAS, E. V. S. Dependência espacial de atributos químicos em área cultivada com cana-de-açúcar em Pereira Barreto, SP. Revista Ciência Agronômica, Fortaleza, v.38, n.4, p.350-359, 2007.

CARVALHO, M.P.; TAKEDA, E.Y.; FREDDI, O.S. Variabilidade espacial de atributos de um solo sob videira em Vitório Brasil (SP). Revista Brasileira de Ciência do Solo, Viçosa, v.27, n.4, p.695-703, 2003.

CARVALHO, S. R. L.; VILAS BOAS, G. S.; FADIGAS, F. S. Variabilidade espacial de atributos físicos e químicos em solos originados nos sedimentos da formação barreiras. Cadernos de Geociências, Salvador, v. 7, n. 2, p. 63-79, 2010.

CAVAlCANTE, E. G. S.; ALVES, M. C.; SOUZA, Z. M.; PEREIRA, G. T. Variabilidade espacial de atributos químicos do solo sob diferentes usos e manejos. Revista Brasileira de Ciência Solo, Viçosa, v. 31, p. 1329-1339, 2007.

CORTEZ, J. W.; ALVES, A. D. S.; MOURA, M. R. D.; OLSZEVSKI, N.; NAGAHAMA H. J. Atributos físicos do argissolo amarelo do semiárido nordestino sob sistemas de preparo. Revista Brasileira de Ciência do Solo, Viçosa, v.35, n.4, p.1207-1216, 2011.

CRUZ, C. D.; REGAZZI, A. J. Modelos biométricos aplicados ao melhoramento genético. 2.ed. rev. Viçosa: UFV, 2001, 390p.

CRUZ, J. S.; ASSIS JÚNIOR, R. N.; MATIAS, S. S. R.; CAMACHO-TAMAYO, J. H.; TAVARES, R. C. Análise espacial de atributos físicos e carbono orgânico em argissolo vermelho-amarelo cultivado com cana-deaçúcar. Ciência e Agrotecnologia, Lavras, v. 34, n. 2, p. 271-278, 2010.

DALCHIAVON, F. C.; CARVALHO, M. P.; MONTANARI, R.; ANDREOTTI, M.; PANOSSO, A. R. Produtividade da cana-de-açúcar: variabilidade linear e espacial entre componentes tecnológicos e da produção. Revista Bioscience Journal, Uberlândia, v. 30, p. 390-400, 2014. 
Empresa Brasileira de Pesquisa Agropecuária - EMBRAPA. Sistema brasileiro de classificação de solos. 3. ed. Brasília: Embrapa Solos, 2013, 353 p.

Empresa Brasileira de Pesquisa Agropecuária -EMBRAPA. Centro Nacional de Pesquisa de Solos. Manual de métodos de análise de solo. Rio de Janeiro, 1997. 212p.

GOOVAERTS, P. Geostatistical tools for characterizing the spatial variability of microbiological and physicochemical soil properties. Biology and Fertility of Soils, Berlin, v. 27, n. 4, p. 315-334, 1998. http://dx.doi.org/10.1007/s003740050439

HAIR J. R.; ANDERSON, R. E.; TATHAM, R. L.; BLACK, W. C. Análise multivariada de dados. Porto Alegre, Bookman, 2005. 211p.

HOFFMANN, R. Componentes principais e análise fatorial. Piracicaba: Departamento de Economia e Sociologia Rural. Escola Superior de Agricultura "Luiz de Queiroz", Universidade de São Paulo, 1992. 25p. (Série Didática n. 76).

ISAAKS, E. H.; SRIVASTAVA, R. M. An introduction to applied geoestatistics. New York, Oxford University Press, 1989. 561p.

JEFFERS J.N.R. An Introduction to System Analysis: with Ecological Applications. E. Arnold Publ., London, 1978.198p.

MARQUES, J.; SIQUEIRA, D. S.; CAMARGO, L. A.; TEIXEIRA, D. B.; BARRÓN, V.; TORRENT, J. Magnetic susceptibility and diffuse reflectance spectroscopy to characterize the spatial variability of soil properties in a Brazilian Haplustalf. Geoderma, Amsterdam, v. 219-220, p. 63-71, 2014.

http://dx.doi.org/10.1016/j.geoderma.2013.12.007

MINITAB RELEASE 14.1. Statistical Software. US/ Canadá. 2000.

MONTANARI, R.; PEREIRA, G. T.; MARQUES JÚNIOR, J.; SOUZA, Z. M.; PAZETO, R. J.; CAMARGO, L. A. Variabilidade espacial de atributos químicos em Latossolo e Argissolos. Ciência Rural, Santa Maria, v. 38, n. 5, p. 1266-1272, 2008. http://dx.doi.org/10.1590/S0103-84782008000500010

OLIVEIRA, I. A.; CAMPOS, M. C. C.; FREITAS, L.; SOARES, M. D. R. Caracterização de solos sob diferentes usos na região sul do Amazonas. Acta Amazônica, Manaus, v. 45, n. 1, p. 1-12, 2015.

http://dx.doi.org/10.1590/1809-4392201400555

PELUCO, R. G.; MARQUES JR, J.; SIQUEIRA, D. S.; BARBOSA, R. S.; PEREIRA, G. T.; TEIXEIRA, D. B. Mapeamento do fósforo adsorvido por meio da cor e da suscetibilidade magnética do solo. Pesquisa Agropecuária Brasileira, Brasília, v. 50, p. 259-266, 2015. http://dx.doi.org/10.1590/S0100204X2015000300010

PELUCO, R. G.; MARQUES JR, J.; SIQUEIRA, D. S.; PEREIRA, G. T.; BARBOSA, R. S.; BARBOSA, R. S.; TEIXEIRA, D. B.; ADAME, C. R.; CORTEZ, L. A. Suscetibilidade magnética do solo e estimação da capacidade de suporte à aplicação de vinhaça. Pesquisa Agropecuária Brasileira, Brasília, v. 48, p. 661-672, 2013. http://dx.doi.org/10.1590/S0100-204X2013000600012

PLANT, R. E. Site-specific management: the application of information technology to crop production.

Computers and Electronics in Agriculture, Amsterdam, v.30, n.1/3, p.9-29, 2001.

http://dx.doi.org/10.1016/S0168-1699(00)00152-6

ROBERTSON, G. P. GS+ geostatistics for the environmental sciences: GS+ user's guide. Plainwell: Gamma Design Software, 1998, 152p. 
SILVA, S. A.; LIMA, S. S.; XAVIER, A. C.; TEIXEIRA, M. M. Variabilidade espacial de atributos químicos de um Latossolo LermelhoVamarelo húmico cultivado com café. Revista Brasileira de Ciência do Solo, Viçosa, v.34, n.1, p.15-22, 2010.

SILVEIRA, P.M.; ZIMMERMAN, F.J.P.; SILVA, S.C DA; CUNHA, A. A. Amostragem e variabilidade espacial de características químicas de um latossolo submetido a diferentes sistemas de preparo. Pesquisa Agropecuária Brasileira, Brasília, v. 35, n. 10, p. 2057-2067, 2000. http://dx.doi.org/10.1590/S0100204X2000001000018

SOUZA, G. S.; LIMA, J. S. S.; SILVA, S. A.; OLIVEIRA, R. B. Variabilidade espacial de atributos químicos em um Argissolo sob pastagem. Acta Scientiarum Agronomy, Maringá, v. 30, n. 4, p. 589-596, 2008. http://dx.doi.org/10.4025/actasciagron.v30i4.5322

SOUZA, Z. M.; MARQUES JÚNIOR, J.; PEREIRA, G. T.; MONTANARI, R.; CAMPOS, M. C. C. Amostragem de solo para determinação de atributos químicos e físicos em área com variação nas formas do relevo. Científica, Jaboticabal, v. 34, n. 2, p. 249-256, 2006.

TRANGMAR, B. B.; YOST, R. S.; UEHARA, G. Application of geostatistics to spatial studies of soil properties. Advances in Agronony, Amsterdam, v. 38, n. 1, p. 54-94, 1985.

VIEIRA, S. R. Geoestatística em estudo da variabilidade espacial do solo. In: NOVAIS, R. F. DE; ALVAREZ V., V. H.; SCHAEFER, C. E. G. R. (Ed.) Tópicos ciência do solo, Campinas: Sociedade Brasileira de Ciência do Solo, Viçosa, v. 1, p. 1-54. 2000. http://dx.doi.org/10.3733/hilg.v51n03p075

VIEIRA, S. R.; HATFIELD, J. L.; NIELSEN, D. R.; BIGGAR, J.W. Geoestatiscal theory and application to variability of some agronomical properties. Hilgardia, Riverside, v. 51, n. 3, p. 1-75, 1983.

WARRICK, A. W.; NIELSEN, D. R. Spatial variability of soil physical properties in the field. p. 319-344. In: Hillel, D. (Ed.). Applications of soil physics. New York, 1980. http://dx.doi.org/10.1016/b978-0-12348580-9.50018-3 